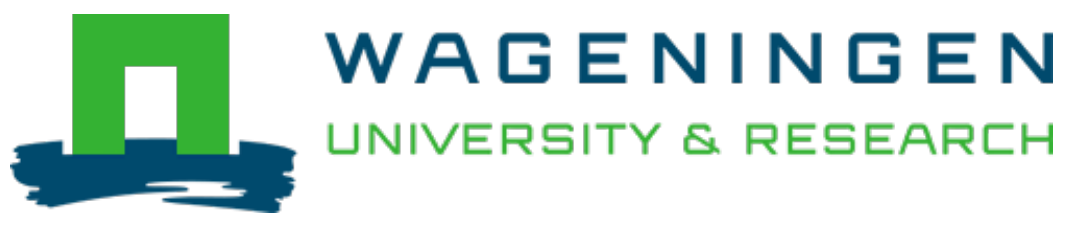

\title{
Hybridizing the commons. Privatizing and outsourcing collective irrigation management after technological change in Spain
}

\author{
World Development \\ García-Mollá, Marta; Ortega-Reig, Mar; Boelens, Rutgerd; Sanchis-Ibor, Carles \\ https://doi.org/10.1016/j.worlddev.2020.104983
}

This article is made publicly available in the institutional repository of Wageningen University and Research, under the terms of article $25 \mathrm{fa}$ of the Dutch Copyright Act, also known as the Amendment Taverne. This has been done with explicit consent by the author.

Article 25 fa states that the author of a short scientific work funded either wholly or partially by Dutch public funds is entitled to make that work publicly available for no consideration following a reasonable period of time after the work was first published, provided that clear reference is made to the source of the first publication of the work.

This publication is distributed under The Association of Universities in the Netherlands (VSNU) 'Article $25 \mathrm{fa}$ implementation' project. In this project research outputs of researchers employed by Dutch Universities that comply with the legal requirements of Article $25 \mathrm{fa}$ of the Dutch Copyright Act are distributed online and free of cost or other barriers in institutional repositories. Research outputs are distributed six months after their first online publication in the original published version and with proper attribution to the source of the original publication.

You are permitted to download and use the publication for personal purposes. All rights remain with the author(s) and / or copyright owner(s) of this work. Any use of the publication or parts of it other than authorised under article $25 \mathrm{fa}$ of the Dutch Copyright act is prohibited. Wageningen University \& Research and the author(s) of this publication shall not be held responsible or liable for any damages resulting from your (re)use of this publication.

For questions regarding the public availability of this article please contact openscience.library@,wur.nl 


\title{
Hybridizing the commons. Privatizing and outsourcing collective irrigation management after technological change in Spain
}

\author{
Marta García-Mollá a , Mar Ortega-Reig a , Rutgerd Boelens ${ }^{\mathrm{b}, \mathrm{c}}$, Carles Sanchis-Ibor ${ }^{\mathrm{a}, *}$ \\ ${ }^{a}$ Centro Valenciano de Estudios del Riego, Universitat Politècnica de València, Camí de Vera s/n, 46022 València, Spain \\ ${ }^{\mathrm{b}}$ Department of Environmental Sciences, Wageningen University, the Netherlands \\ ${ }^{\mathrm{C}}$ CEDLA Centre for Latin American Research and Documentation, University of Amsterdam, the Netherlands
}

\section{A R T I C L E I N F O}

\section{Article history:}

Accepted 4 April 2020

\section{Keywords:}

Irrigation

Privatization

Outsourcing

Coproduction

Technological change

Common-pool resources management

\begin{abstract}
A B S T R A C T
During the last decades, several regions of the world have experienced an increasingly forceful penetration by commercial service companies into irrigation water management, altering the institutional structures and procedures of common-pool resources management. In many cases, private-sector penetration takes place when water user organizations require a company to implement high-tech water control such as pressurized irrigation systems, as part of 'modernization policies'. This study focuses on four representative cases of these processes with differing degrees of private-enterprise penetration in the Valencia Region (Spain). The research analyzes the strategies of collective-private confrontation and collaboration that are emerging in irrigator communities, and characterize how they affect the management of these irrigation systems. Results show how private enterprise intrusion has unequally affected the interactions between the different components of these irrigation systems. This has created different hybrids between private and common pool-resources management institutions, as well as different autonomies, dependencies and socio-political subjects. Users' capacity to guide this coproduction process and maintain local control over their irrigation systems is essential to ensure the stability and preserve the robustness of each irrigation system. The quality of human capital and the recognition of collective water management values makes irrigation entities more robust vis-à-vis external pressures and disturbances, which in some of the cases analyzed have generated major social conflicts.
\end{abstract}

(c) 2020 Elsevier Ltd. All rights reserved.

\section{Introduction}

In 1995, a severe drought that affected the Spanish Mediterranean regions, had a catalyzer effect on the national water policy, and paved the way to the expansion of water-saving technology development all over the country (García-Mollá, Sanchis-Ibor, Ortega, \& Avellà, 2013). In this context, drip irrigation was perceived as a win-win formula to increase the reliability of agricultural water supply and to improve water productivity (Alcón, Arcas, De Miguel, \& Fernández-Zamundio, 2009; López-Gunn, Zorrilla, Prieto, \& Llamas, 2012). An alliance was formed between administrations, irrigation communities, professional associations, and private companies that, for different reasons and with different benefits and burdens, pushed for the installation of

\footnotetext{
* Corresponding author.

E-mail addresses: mgarmo@esp.upv.es (M. García-Mollá), marorrei@upv.es (M. Ortega-Reig), rutgerd.boelens@wur.nl (R. Boelens), csanchis@hma.upv.es (C. Sanchis-Ibor).
}

micro-irrigation (Sanchis-Ibor, García-Mollá, \& Avellà, 2016; García-Mollá et al., 2019). As a result, after a strong public and private investment, today micro-irrigation is installed in two million hectares in Spain, replacing gravity irrigation in most of this area (2019).

Numerous historical irrigation systems have adopted this technology, which has altered deeply-rooted agricultural water distribution practices, fertigation procedures and organizational structures. Because of the multiple effects it has caused, the shift from gravity to drip irrigation can be considered to be one of the most impactful changes in Mediterranean irrigation since the medieval Arab agricultural revolution. Recent research in Spain and other countries has mainly focused on the multiple effects of this technological shift in terms of water resources availability (Van der Kooij, Zwarteveen, Boesveld, \& Kuper, 2013; Berbel, Gutiérrez-Martín, Rodríguez-Díaz, Camacho, \& Montesinos, 2015; Venot et al., 2017; Grafton et al., 2018); energy use (Fernández-G arcía, Rodríguez-Díaz, Camacho-Poyato, Montesinos, \& Berbel, 2014; Soto-García, Martínez-Alvarez, García-Bastida, Alcon, \& 
Martin-Gorriz, 2013; Rodríguez-Díaz, Pérez-Urrestarazu, Camacho-Poyato, \& Montesinos, 2011); and productivity (Cai, Rosegrant, \& Ringler, 2003; Contor \& Taylor, 2013; Ahmadzadeh, Morid, Delavar, \& Srinivasan, 2015).

Comparatively, researchers have paid less attention to the institutional and organizational changes induced by this technological change, which in a number of collective irrigation systems has limited farmers' capacity of decision making, has hindered local control and collective action, and has generated external dependence, among other effects (Hoogesteger van Dijk, 2017; Ortega-Reig, Sanchis-Ibor, García-Mollá, \& Palau-Salvador, 2017; Sanchis-Ibor, Boelens \& García-Mollá, 2017). One of the most significant changes is the outsourcing of certain functions and tasks traditionally developed by collective irrigation institutions.

In a global policy context pushing to privatize and outsource resources and activities traditionally managed by public or local customary administrations (Bakker, 2005; Dupuits, Baud, Boelens, de Castro, \& Hogenboom, 2020; Harvey, 2003; Swyngedouw, 2005), some changes of infrastructure and irrigation techniques in irrigation communities have been accompanied by delegating part or all of their irrigation management to private companies. These companies got into irrigation management by signing Build Operate and Transfer (BOT) contracts to build drip irrigation infrastructure or through formulas to delegate certain operation and maintenance (O\&M) services once the new technology is installed. This has positioned private enterprise as a new, often pivotal element of the irrigation system, acting as the intermediary among users, infrastructure and water resources.

Because of the lack of research on these processes, it is necessary to analyze how outsourcing and privatization take place in irrigation communities and which implications they have on the collective management of water. Such analysis will require a variety of case studies in a given region, considering diverse geographical and institutional contexts, and the diverse range of privatization arrangements. Therefore, this article analyzes different case studies in Spanish irrigation, in the region of Valencia. Our study presents four representative cases with differing degrees of private-enterprise penetration in collective irrigation management. The main research aims are to: analyze strategies of collective-private confrontation and collaboration that are emerging in irrigator communities; and characterize how they affect collective management of irrigation systems.

\section{Privatizing and outsourcing irrigation management}

Collective management of irrigation systems is one of the forms of common-pool resources governance that has achieved stronger recognition (Ostrom, 1992; Roth, Boelens, \& Zwarteveen, 2015; Suhardiman et al., 2017). Irrigator communities have shown, in numerous places the world round, that they are capable of resolving internal conflicts, managing water with their own norms, often quite effectively, using their own notions of equity and sustainability (e.g., Glick, 1970; Maass \& Anderson, 1978; Mabry, 1996; Roth, 2014; Hoogesteger, 2015; Hunecke, Engler, Jara-Rojas, \& Marijn Poortvliet, 2017; ) and Jackson, 2018; Wilson, 2019). Far from being a social panacea, they coexist with situations of conflict and inequality (Mayer, 2002; Calatayud, 2008; Perreault, 2008) and there are cases of deficient administrative and technical performance or corruption (D'Amaro, 2018; Kibaroglu, 2020). However, despite these deficiencies, traditional institutional forms of collective management of irrigation (communities, syndicates, associations, cooperatives, etc.) have received legal endorsement from numerous national water governance bodies and, in the recent decades, some states have transferred local water management to users, promoting the creation of new irrigation communities or water user associations (Garcés-Restrepo, Vermillion, \& Muñoz, 2007; Vermillion, 1997; Groenfeldt \& Svendsen, 2000).

In the two first decades of the 21st century, new management formulas have let private enterprise into irrigation management, replacing or accompanying state-led management or collective management institutions. Governments and multilateral organizations (e.g., 2007; World Bank, 2005) have encouraged establishment of Public-Private Partnerships (PPPs), either in the form of public contracts or as Public Service Delegations (PSDs) established as leases, concessions, divestitures or BOT contracts. A discourse has consolidated that recommends for the State to withdraw from directly managing irrigation, attempting to involve investors and private companies to work in collaboration with users (MandriPerrott \& Bisbey, 2016; Rap, 2006; 2007; World Bank, 2005). PPP proponents justify the need to incorporate private enterprise for several reasons (Préfol et al., 2006; Trier, 2014): i) users and governments lack the technical or financial capacity to make investments or manage new infrastructure; ii) the private sector's greater experience in managing water supply and sanitation; and iii) the private sector's greater efficiency in managing such functions as operating performance, maintenance and management (OMM).

Whereas some of these institutions have proposed PPP in irrigation as an optimal strategy, others had already argued that this tool must be used carefully and only in certain contexts. In general, both these groups have recommended combining PPP formulas and technological modernization with Participatory Irrigation Management (PIM) to facilitate local acceptance of market thinking in OMM, so water user organizations can outsource some private services for specific tasks (Trier, 2014). Other authors have taken a more critical position. Based on failure experienced or negative outcomes (e.g., Boelens, Hoogesteger, \& Baud, 2015; Houdret, 2012; Houdret \& Bonnet, 2013; Venot, Kuper, \& Zwarteveen, 2017) they challenge some of the foundational premises underlying private sector participation in community irrigation. In this regard, the alleged success of PPPs in the water supply and sanitation subsector has been compared with examples of failure and a growing re-municipalization of these services (Pigeon et al., 2012; Lobina, Kishimoto, \& Petitjean, 2015; Lobina, Weghmann, \& Marwa, 2019). At the same time, PPPs in irrigation have been questioned because private enterprise makes its way on the basis of market-based arrangements that are markedly different from the principles of collective irrigation management (Reimer, Lyons, Ferguson, \& Polanco, 2008; Boelens, 2015; Sanchis-Ibor, García-Mollá, \& Avellà, 2017; Brandshaug, 2019). An entire critical current presents this wave of privatization as a strategy for water dispossession/grabbing (Bond, 2004; Swyngedouw, 2005; Vos \& Boelens, 2014) and warns of the risks and dis-economies that commodification, privatization and marketization of water resources or irrigation services may generate (Bakker, 2013; Andersen, 2019; Dupuits et al., 2020; Paerregaard, 2019; Stensrud, 2019; Ullberg, 2019).

There is definitely a controversy, further entangled by ideological leanings, about the foundations and consequences of privateenterprise participation in irrigation management, which asks for a thorough and field-grounded case-by-case analysis of this global phenomenon. Analyzing the transfer of functions from collective to private management poses a terminological problem. Different authors and contexts call these operations privatization or outsourcing. These labels have underlying subjective or ideological connotations, which tend to dignify or discredit these operations in most international languages. Overall, theorists of neoliberalism (e.g., Savas, 1987; 1999) and academic dictionaries (MerriamWebster, Spanish Royal Academy, Académie Française, among others) take "privatization" to mean any transfer of institutions or activities from public to private, and "outsourcing" is usually considered to be a kind of privatization that transfers certain public services to private enterprise without loss of control or supervision 
over them by the public administration (or community authority). In recent years, several authors have confronted both privatization and outsourcing as related but gradually differing concepts, setting the boundary between these two terms at whether the public/community sphere loses control over the element or function transferred (Bond, 2004; Caamaño, Gimeno, Quintero, \& Sala, 2017; Suhardiman, Nicol, \& Mapedza, 2017).

The problem is more complex in the case of irrigation management, because "privatization" is often used in this sector to describe IMT, transferring public irrigation systems to collectively managed institutions. Accordingly, to avoid greater terminological ambiguity, Groenfeldt and Svendsen (2000) proposed the term "userization" to describe management transfer from a publicsector agency to a users' association; this term has not yet spread into public and academic debate. Next, while this "userization" generally refers to State policies transferring water management tasks to users (presumably 'participatorily' but in practice often top-down), the term "collectivization" - or re-collectivization, as the case may be - describes private/public transfer to collective community resource management, and often indicates recent bottom-up experiences whereby users aim and claim to get back water control and autonomy (e.g., Boelens, 2015; Sanchis-Ibor, Boelens \& García-Mollá, 2017)

This study finds these terms subjectivized when they are used in practice. On the one hand, critics of such contracts between community and private-enterprise institutions have used the notion 'privatization' while, on the other, these contracts' defenders rather use 'outsourcing' ('externalización' in Spanish), and they even correct interviewers if the latter do not use the term that detractors and advocates consider most appropriate. We have respected these expressions throughout the study, when employed by interviewees in their arguments. Nevertheless, to classify and describe the processes observed in the different case studies, we have differentiated between cases or formulas that are clearly outsourcing, and contracts in which - since irrigators lose control over management - we feel 'privatization' is more accurate. However, in general, we are witnessing hybridization of these concepts through the whole range of agreements that can be reached between a community that manages its resources collectively and private companies: privatization or outsourcing often create a hybrid irrigation system sharing characteristics and strategies from both collective and private management.

In this way, our analysis also contributes to the longstanding debate on 'coproduction' of (water-based) public goods and services by multiple actors. This debate importantly concentrates on the strengths/weaknesses of Ostrom (1996) analysis where State and community institutions interact and entwine in forms of conflict and cooperation. These State-community interactions result in particular coproductions of public goods and services, technologies, knowledge systems and social order, and water policies and governance structures (Jasanoff, 2004; Joshi \& Moore, 2004; Bridge \& Perreault, 2009: for a critical overview see Goodwin, 2019). Coproduction is, however, also an important feature when community and private institutions mix and hybridize in diverse ways. Also here it is crucial to see how it is not just a matter of making available and managing water resources or providing water services but, in line with Mitlin (2008), how communityprivate sector coproduction crafts new political subjects, relations and institutions, which may strengthen or weaken water user collectives' autonomies (see Goodwin, 2019).

\section{Methodology}

For our study, field work was done by interviewing representatives of irrigation entities, private companies, farmers and several politicians involved in the privatization and outsourcing processes analyzed. Of the different cases identified in the Valencia Region, to show a complete overview of the range of cases, we have selected a sample of four examples of different degrees of delegating functions to private enterprise, which have generated differing reactions and repercussions in local communities. The four irrigator communities analyzed (Acequia Real del Júcar, Sindicat de Regs de Senyera, Vall de Càrcer i Sellent and Pou de la Penya de l'Hedra) have adopted drip irrigation now in the 21st century and devote most of their farming activity to fruit trees, mainly citrus (Fig. 1).

The irrigator communities are entities recognized by the state to hold collective water rights for irrigation, according to the current (1985) Water Law and historical legislation (1866 and 1879 water laws). They are in charge of O\&M works, transfering water costs to farmers and participating in some committees of the public river basin agencies (Confederaciones Hidrográficas) for water governance. The sovereign organ of the community is the general assembly formed by all the members, which regularly elects a government board as executive organ, and an irrigation jury to solve internal conflicts (Sanchis-Ibor, García-Mollá, Calafat, \& Vega, 2009). The government board makes strategic community decisions (such as drip irrigation adoption or externalization), which must be yearly ratified by the general assembly (together with the annual budget). Three water supply companies were involved in the analyzed privatization or outsourcing processes: Operagua, Tecvasa and Aqualogy. Operagua belongs to the Global Omnium-Aguas de Valencia group, which has a long experience in this area. It was founded in 1890. It is one of the most renowned water management companies at the national level, with current projects in more than 300 municipalities in Spain, Latin America, Africa and Asia. Aqualogy is a company engaged in water management solutions in Europe and Latin America, belonging to the AGBAR group (Aguas de Barcelona), founded in 1867. This group was absorbed by Suez (now Suez Environnement) and Criteria CaixaCorp in January 2008. Both Operagua and Aqualogy provide services at different levels for several irrigation communities in Spain. Conversely, Tecvasa is a small local company, founded in 1990, that has focused their activity on urban water supply in rural areas. Apart from some local construction projects, the company manages water supply systems and sewage treatment plants in 30 small municipalities, most of them in Valencia Region. The project in the Sindicat de Regs de Senyera, one of the selected study cases, was its first attempt to penetrate in the agricultural management of water.

The semi-structured interviews were done in June and July from 2014 to 2017, and in December and January from 2016 to 2018. Except in the case of Pou de la Penya de l'Hedra, presidents, members of the government boards, technicians and some operators were interviewed 2 times. In total we interviewed 16 representatives of the irrigation communities, plus 5 representatives of the private companies, 4 majors and 28 farmers. In 3 out of the 4 cases, some interviews were done exclusively by the authors, and others by the authors and groups of 4-5 students. Interviews were held in Spanish or Valencian, at the irrigation community offices or at the bars were farmers use to meet for breakfast. Farmers and technicians guided the authors to visit the irrigation system, and they also provide documentation from their institutions. Other documentation was obtained from the Basin Authority and the Regional Government, and additional information on social conflicts was collected from the two main regional newspapers and the local televisions. 


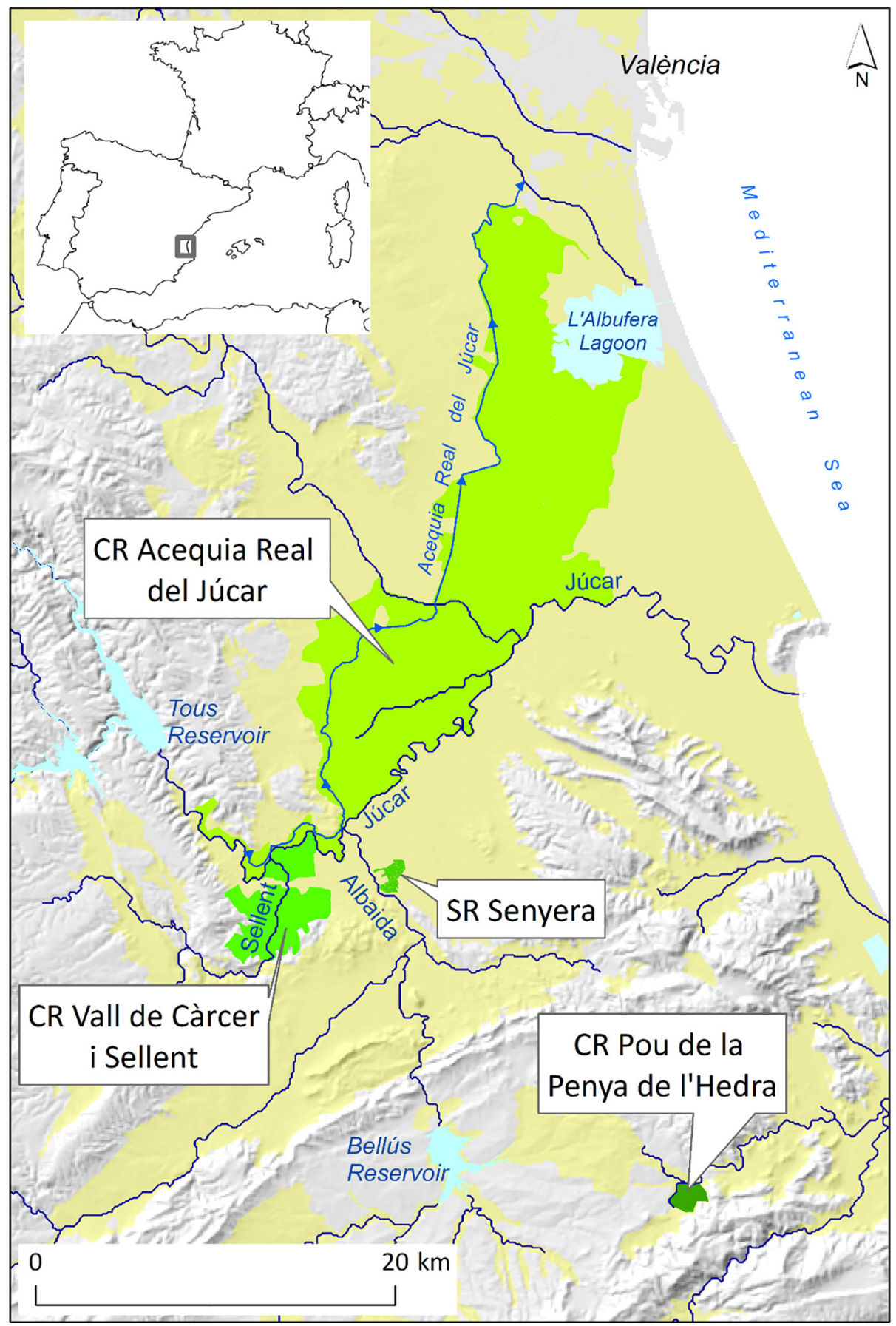

Fig. 1. Location of the four study areas. Sandy color represents other irrigated lands within the Valencia Region.

\section{Four irrigation communities delegating collective management functions}

4.1. Pou de la Penya de l'Hedra: A company that manages the water, provides services and listens to users; a community that delegates, trusts and controls

The Community of Irrigators of Pou de la Penya de l'Hedra is a small entity comprising 193 farmers in the municipality of Terrateig. Unlike other areas in the region, in Terrateig farmers had no significant tradition of collective management of water. In the late 20th century, little area was watered in Terrateig, because they had only a spring, which could barely supply a maximum of 35 ha.
Dry farming predominated (190 ha). The Mayor helped get technical and financial assistance to undertake an irrigation modernization and expansion project, constructing a drip irrigation network. Work began in 2003, costing a total of $0.9 \mathrm{M} €$, financed in equal portions by the regional administration and the users. The project covered an area of 164 ha, but only 67 ha are currently irrigated. The modernization built two large reservoirs $\left(0.6 \mathrm{Mm}^{3}\right.$ each), which provide enough pressure for drip irrigation. Changing the irrigation technique doubled the irrigated area, without changing the administrative concession of groundwater, or affecting piezometric levels, stabilized at about $150 \mathrm{~m}$ depth.

The new irrigation technique caused farmers a problem: they had never formed any legal institution to manage their irrigation. 
In 2002, they set up a society and begin looking for technical support, having little experience with drip irrigation and no trained staff to manage it. They had to find a company to maintain the new system and also handle management for the community. In 2006, the irrigators' collective contacted several companies, comparing their conditions, and chose Operagua.

The company has taken over all the irrigation entity's management tasks. It does the administrative work - including collecting community members' fees, distributing the irrigation water and maintaining infrastructure with preventive and repair work. The community's current main function is to have the administrative water use license and supervise the company's activities. They also hold a general assembly twice a year, at which the company's technical staff reports those attending about how the community system is doing and answers any queries users have.

Company technicians, community representatives and municipal staff agree that this delegation of functions is the most positive option to govern their water use system, in view of its small size and lack of personnel and experience in managing pressurized irrigation networks. Opinions gathered from users are favorable and reflect generalized satisfaction with the company's services. The users, owners of the system who collectively chose a reliable company, feel the company's services are positive and they especially appreciate its capacity to detect leaks in the network, and deal with suppliers, because the company is large enough and quite positioned in Spain's water sector. As one farmer put it: "When something breaks, they fix it right up, and they help with things like red tape".

The most significant disagreements involve the company's management costs. The Vice Mayor is also a farmer, and thinks the company is really expensive. If a farm is no longer profitable, that user can quit the system at no charge. Operagua then removes the water meters and takes them out of the system. Late payment is not a problem, either. The company sends numerous reminders before cutting off the service, and the final decision is made by the collective irrigators' entity.

Users, who are the water governors, having collectively deliberated and chosen the most suitable company, control the system critically, but trust the company. The spokesperson for Operagua said that the system's success is based on trust. From the very outset, the company felt that building such trust was a key element to keep the contract in the long term and therefore they strive to satisfy all demands from the entity's members and any doubts that arise. After 10 years of working together, this satisfaction and mutual trust have increased over time. Now, the Operagua technician tells us, "I can go to the bar without getting shouted at, just have a cup of coffee and chat with the farmers", quite unlike what has happened in other communities of irrigators.

\subsection{Acequia Real del Júcar: Failed outsourcing}

The Irrigator Community of Acequia Real del Júcar (ARJ) is one of the region's highest-profile irritation entities. Nearly 25,000 farmers from 22 municipalities belong to ARJ, watering nearly 19,000 ha with water taken from the Júcar River by a canal built in 1258 . The entity is organized as a community of 22 local communities, whose government boards elect the government board of the institution. The ARJ has historically played a leading role in water governance in the region, both in the creation of the Jucar Basin Authority in 1934 and in the foundation of the national federation of irrigation communities (FENACORE) in 1955. They grow mostly oranges, persimmons, and rice. In 2006, after completing the new general conduction, ARJ began implementing drip irrigation in most of their irrigated zone. This operation, financially supported by the Government, has not been completed yet, but there are 16 sectors (5000 ha) that have adopted this technology.
Once the work was finished on the first sectors, irrigation began provisionally, though the basin authority, the Confederación Hidrográfica del Júcar had not transferred the infrastructure to irrigators. During that period, this basin authority obliged ARJ to engage a private company of "well-recognized solvency" to operate the new irrigation network's O\&M, and initially other tasks as well (analytics, quality plan, training workers). At the same time, ARJ developed a strategic human resources plan, to organize a team that could manage the new technology and maintain the facilities, incorporating new professionals into the entity's staff. Thus, the irrigation entity was soon able to take over system management and limited the company's services (Operagua) to a maintenance and preventive conservation contract for the installations. The initial results of outsourcing were satisfactory, but as time wore on, as the community of irrigators learned more about how the new irrigation system worked, their perception changed. They detected room for improvement in certain aspects of the service being provided (notably, recurring breakdown of flow meters) and non-involvement of the company's employees in improving service quality. Consequently, in 2018, and due to the irrigator community's dissatisfaction with the service provided by the maintenance staff hired by Operagua, they hired a small company exclusively to perform these functions, which cut their costs and significantly improved service quality, reducing flow-meter breakdown to a minimum.

Managing automated devices was not included in this transfer: telecontrol systems were designed by the company that built the drip irrigation network, which continued with a contract to supply replacement parts and perform maintenance and repairs of these telecontrol systems. In 2011, ARJ introduced their own personnel for maintenance tasks and limited the functions for which this company was hired to repairs and replacing parts. This company was subsequently replaced by another, which cut repair and replacement costs by $150 \%$, by introducing more efficient, durable materials.

In general, the water users entity's technicians were not satisfied by the criteria and practices of the companies who designed the networks, because they had given priority to keeping their price of construction or installation as low as possible regardless of the resulting maintenance costs. In their opinion, as one of the leaders put it, "these companies have pulled the wool over our eyes". Another leader explained that they habitually "sell cheaper technology that is more expensive to maintain". An example is the design of sheds to protect hydrants. They are so small that a maintenance technician cannot work in them standing up and they must be lifted with a forklift to perform any repairs. Similar problems have been detected in filtering and fertilizing systems, with original designs, meeting no industrial standards, which make maintenance more expensive and force or attempt to force irrigators to be dependent on the installing company.

Nonetheless, over time ARJ has replaced these devices with standardized industrial formats, to reduce economic costs and external dependence. Currently they only hire companies for some specific O\&M tasks (such as fertilizer provision and repairing electrical breakdowns). These concrete services are provided according to the assessment and under oversight by ARJ technicians, to "avoid being hoodwinked anymore". All other OMM operations are done directly by ARJ personnel, to maintain their autonomy.

\subsection{Vall de Càrcer i Sellent: brief outsourcing, failed privatization}

The Irrigators Community of Vall de Càrcer $i$ Sellent comprises 1,700 farmers who water 1,600 ha in the municipalities of Sellent, Càrcer, Cotes, Alcàntera del Xúquer and Beneixida. The irrigated area is divided into two zones bound by the Acequia de Escalona canal: the Part Baixa (literally, low part), of approximately 
600 ha, are historical irrigation areas, using surface water from the Júcar and Sellent Rivers, by gravity flow they term blanketing: "riego a manta". The Part Alta (upper part) is an expansion made in the early 20th century covering about 1000 ha, using the leftover water, pumped up from the Part Baixa, plus ground water. The median property size is 0.25 ha, especially fragmented in the Part Baixa, whereas plot size is larger in the Part Alta, and some plots are over 5 ha. In the Part Alta, two companies own nearly 300 ha, which assures them significant weight in the Governance Board, above all at times when smaller owners are not well organized. The General Assembly meets twice a year and the Governance Board once a month.

In 2007, the community approved a project to change over to drip irrigation for the Part Alta and in 2010 the community got five million Euros in grants for the main works (covering 100\%). Work for the secondary canals totaled eight million Euros, half of which was contributed by the Regional Government and the other half covered by users. All system users, in both the Part Alta and the Part Baixa, had to contribute to financing the investment (444€/ha for 15 years), whether they were going to install drip irrigation or not in their own sector or plot. The network is built, but $20 \%$ is not operational because of construction defects.

After drip irrigation installation was finished, in October 2013, the Governance Board announced they had hired the Aqualogy company to manage and maintain the new network. They justified this outsourcing by the lack of trained personnel in the irrigator community. The company was supposed to hire the people who had been responsible for performing these functions in the irrigators' community, though the latter were fearful of the change. Some irrigators protested against this initiative, calling an information assembly, and began organizing to stop the privatization, creating an association called Comptes Clars (Clear Accounts). This association also demanded an audit of the entity's accounts.

Comptes Clars gathered signatures to call for a Special Assembly, which was held in December 2013. The Governance Board won the vote, but had to confront growing pressure from the opposition. Multiple problems with the drip infrastructure and increased irrigation fees to pay for the drip-irrigation investment paved the opposition's way. Many of them refused to pay these higher rates, rejecting the Governance Board's policy. In turn, the Governance Board used unethical methods to defuse the opposition, such as changing proxy forms a few days prior to the general assembly, to keep the opposition from gathering enough proxy votes. This procedure earned them two complaints against Governance Board members and several appeals for reversal to the basin authority, the Confederación Hidrográfica del Júcar.

After all this conflict which, in the words of the President at the time, "generated much violence", the irrigators community withdrew the project to privatize all management. However, this withdrawal, forced by the increasing pressure, did not prevent the irrigators' community (dominated by the large-scale farmers in the Part Alta, many using drip irrigation) from engaging the company for irrigation system O\&M. Their strategy, according to the President at the time, was to pursue a slower, more discreet transferal of the various functions to companies. So, they soon (in 2015) also proposed to outsource administrative management and fee collection, which never happened.

Finally, the Comptes Clars association became a political party and ran in the municipal election. Their candidate became Mayor of Càrcer. In January 2017, the Governance Board's term of office ended, they were not reelected, and the new members began reviewing the entity's economic management of the irrigation system. These audits revealed a number of dysfunctions in the new irrigation system and sued the previous President, alleging infractions, and bringing suit in the courts for fraud, in December 2018.
Representatives of the former Governance Board argue that this was not privatization, but merely outsourcing of services, on two grounds: The entity's employees lacked the technical capacity to manage more sophisticated irrigation technology, and user fee collection required improvement. They felt that the technology change in the Part Alta required personnel experienced in managing pressurized networks, and irrigators' high arrears in fee payment called for personnel free of personal or family ties with users, to collect more effectively. In their view, opposition to these measures was socially and politically motivated by a conflict of interests between large and small owners: in favor of and against privatization, respectively.

The Comptes Clars opposition did not dispute the problem of late payment, but pointed to societal conflict as one of its important causes: they asserted that, because of mismanagement, the community collected only half of the $€ 810,000$ that current rates should yield. They agreed about the differing interests between (the more wealthy) Part Alta that favored modernization and privatization and the Part Baixa smallholder irrigators who wanted to continue irrigating more autonomously. Both parties agreed about quantifying the negative impacts of the incipient privatization, which both Comptes Clars and the former Governance Board set at a $21 \%$ increase. This figure is the sum of the company's $11 \%$ profit rate and the $10 \%$ VAT (which is not payable by irrigator communities, but companies do pay VAT). Different from the former Governance Board, opponents believe that incrementally outsourcing services was a strategy to, in the end, privatize all services and governance, so that the Board could conceal the mistakes made during modernization and account management. They argue that, with proper collective management, no company's help is needed, and working collectively would keep operating costs down, protecting farmers whose produce brings low prices.

\subsection{Senyera: privatization and re-collectivization}

Senyera is a municipality of 1169 inhabitants who farm 77.5 ha, mostly orange groves. This land is watered from the Albaida River through a medieval canal known as the Séquia Comuna d'Ènova. Historically, farmers were organized in an entity, the Junta de Regs, whose president was the Mayor of the municipality, but at the beginning of the 20th century they founded the Sindicat de Regs de Senyera, formally separated from the local government. The Sindicat currently manages the water distributed in the municipal area, and it has approximately 150 members, whose average age is quite high (half are over 65).

Introducing drip irrigation began in 2004, when the Sindicat received a proposal from the Senyera local government. The project was submitted to the General Assembly for approval, and the Mayor and a salesperson from a water management company (Tecvasa) explained and defended the transformation project. Only 55 of the community's 235 members attended the assembly, and they approved the project with 47 yea votes. The company pushed the arrangements through and signed the contract a few days later which, among other things, awarded complete system management to the company for 10 years. Farmers and previous members of the Sindicat governing council say this was all confusing, rushed and un-transparent.

Tecvasa immediately started the water works. During 2004, drip irrigation was installed, and the new system began operating. It included a $98,000 \mathrm{~m}^{3}$ reservoir to store river water, and a distribution network with 331 individual connections. This infrastructure soon revealed operating deficiencies because of poor design and construction. The network was oversized, and the reservoir and submersible pumps chosen to pressurize the network were the wrong choice because of their energy inefficiency. Design defects resulted in numerous conduction pipe breakages. Further, 
drip irrigation reduced older trees' yield, by failing to cover their whole root area.

Frustration loomed as irrigators saw themselves losing control over the system. Tecvasa enclosed irrigation meters in metal boxes to keep farmers from checking whether the volume of water reaching their fields matched the company's invoice. This impossibility of checking meters obliged the Governance Board to scrutinize billing in detail, and they began finding many bills with errors, always in the company's favor. The Sindicat lost most of its operational authority, since Tecvasa made all management decisions. The current President observed: "We had to constantly remind Tecvasa that we were the owners, and they were just service providers, but they weren't listening to or understanding us".

O\&M costs more than tripled, from $180 € /$ ha to $572 € /$ ha per year, and the total cost of irrigation reached $1064 € /$ ha per year, when project amortization is counted. The company also made huge profits by introducing centralized fertigation. Fertilizer prices, rarely higher than $400 € /$ ha/year prior to the transformation, reached $1680 € /$ ha for plots with drip irrigation. The contract signed with Tecvasa was also especially costly for the community whenever users paid late. If any irrigator failed to pay on time, the Sindicat as a whole had to cover the shortfall and pay the company directly. The company imposed a no-abandonment clause stipulating that farmers had to pay even if they gave up on their crops and waived their water rights. The company also boosted their profits by reducing irrigation system maintenance to a minimum. Sindicat representatives report that the company took no insurance on the infrastructure and neglected the facilities, especially in their last years, leaving several elements unusable by the end of the contract.

For 10 years, farmers lost their profit margin, transparency and autonomy. Dissatisfaction with management by the company discouraged irrigators from attending general assemblies. However, in the last general assembly of the decade of management by Tecvasa, held to decide about potentially renewing the contract, attendance was massive, and the community decided to recover their control over the irrigation system.

The results from the first year of return to collective management were quite positive, a tremendous economic relief for Senyera's farmers. The community has cut irrigation management costs to $468 € /$ ha, a reduction of $18.1 \%$. Further, fertigation costs dropped by $67.8 \%$ (from $1680 € /$ ha to $541 € /$ ha/year), while trees' conditions improved substantially. Interviewed farmers spontaneously expressed their pride and satisfaction at regaining collective management of their irrigation. When the automatic irrigation system fails, the system operator controls water allocation manually, and farmers speak with him directly when they need concrete changes (e.g. an additional irrigation turn). The user-headed re-collectivization they demanded has restored the transparency and trust that vanished when system administration was privatized.

\section{Hybridization and autonomy in the collective-private management of irrigation.}

Introducing drip irrigation in the València Region is facilitating hybridization of community irrigation system management with private water management companies. Collective-private collaboration and coproduction arises from delegating functions traditionally assumed by collective irrigation management entities, in divergent degrees and intensities, depending on each case. Table 1 compares these actions in each of the four case studies.

In the cases analyzed, the irrigation entities have relinquished or tried to pass on, temporarily or permanently, functions that play a key role in the sustainability of the irrigation system. The robustness of irrigation systems depends on how interactions among four elements are set up: users, managers, infrastructure and resources (Cifdaloz, Regmi, Anderies, \& Rodríguez, 2010). Outsourcing or privatization wedges the company into the irrigation system as another element, redefining relations among the system's other components, creating a hybrid coproduction, which will unavoidably influence overall robustness.

In the case studies, private enterprise intrusion has affected these interactions unequally. In all cases, the company has become an interface between the infrastructure, the social organization, and the other components of the irrigation system, and has altered some of the flows between them. The company totally or partially controls the infrastructure, makes changes in water conveyance and distribution, and affects, with different variations and intensities, users' and managers' decision-making capacity regarding maintenance, management, distribution and fertilization (Table 1). In some cases, the company can position itself to change all interactions among users, managers, infrastructure and resources. That happened in Senyera, where the company also interfered between the Governance Board and the users, by controlling rate-setting and also worsened the relationship between users and water, because it kept them from checking their water consumption. In Pou de la Penya de l'Hedra, the company achieved a very similar penetration, with the exception that, by acting transparently in measuring water supplied, it did not significantly interfere in users' relationship with their water.

The company's penetration and positioning in the irrigation system changes interactions among the system components. How do these changes affect the robustness? These cases show that a private enterprise's arrival is not a sine qua non prerequisite to undermine system's robustness, which depends fundamentally on irrigators' capacity to keep control over the irrigation system after the company's insertion (similar to State penetration and positioning in coproduction processes: see among others, Mitlin, 2008; Boelens et al., 2015; Goodwin, 2019). The four cases show how the particular technical features, socio-organizational and normative contents and actors' agential behaviors and interests regarding hybridization result in deeply diverging routes of coproduction. These steer how autonomies or dependencies are created; and this in turn shapes the socio-technical and political subjects that come to govern the renewed hydrosocial territories. Thereby, keeping irrigators' local control over irrigation depends on making a series of key decisions about privatization or outsourcing, some of which are made when the new technology is introduced.

The technological change is crucial to gauge the impact of private enterprise's entry. In a context of normalcy, the company would find it very difficult to penetrate communities with lengthy historical experience with collective irrigation management. The central role played by technology in an irrigation system means that, when its infrastructure is replaced by one of external origin, certain linkages among different elements of the irrigation system, particularly ties between the social system and the infrastructure, may temporarily be weakened by users' inability to manage the new infrastructure. In fact, in three of the four cases analyzed, interviewees mentioned their unfamiliarity with the new technology and lack of personnel trained in managing it, as the main factor that moved them to seek external assistance to operate it.

Technological changes are almost never limited to merely replacing some hardware with another, but require changes in knowledge systems (cf. Jasanoff, 2004; Boelens, Shah, \& Bruins, 2019; Duarte-Abadía, Boelens, \& Du Pré, 2019) and entail introduction or collective development of new software. Therefore, technographic rather than technological studies (Jansen \& Vellema, 2011; cf. Aubriot, Fernandez, Trottier, \& Fustec, 2018) explain some of the key conflicts and failures with drip irrigation system implementation in several territories (Garb \& Friedlander, 2014; Venot et al., 
Table 1

Water user association (WAU) functions delegated to private companies in the four case studies.

\begin{tabular}{|c|c|c|c|c|c|}
\hline & & $\begin{array}{l}\text { Sindicat de Regs de } \\
\text { Senyera }\end{array}$ & CR de Càrcer i Sellent & CR Acequia Real del Júcar & CR Pou de la Penya de l'Hedra \\
\hline \multicolumn{2}{|l|}{ Period } & $2005-2014$ & 2013-2015 & 2006-Present & 2006-Present \\
\hline Components & Functions & & & & \\
\hline Construction & $\begin{array}{l}\text { Build-Operate- } \\
\text { Transfer }\end{array}$ & Yes & Yes & No & No \\
\hline \multirow[t]{2}{*}{ Conveyance } & $\begin{array}{l}\text { Water } \\
\text { management }\end{array}$ & Company & $\begin{array}{l}\text { Outsourcing planned but } \\
\text { not executed }\end{array}$ & $\begin{array}{l}\text { WUA, Company for automation } \\
\text { 2006-2011. }\end{array}$ & Company \\
\hline & $\begin{array}{l}\text { System } \\
\text { maintenance }\end{array}$ & Company & Company & $\begin{array}{l}\text { Company 2006-2018, exclusive } \\
\text { contract after } 2018\end{array}$ & Company \\
\hline \multirow[t]{5}{*}{$\begin{array}{l}\text { Distribution } \\
\text { system }\end{array}$} & $\begin{array}{l}\text { Water } \\
\text { management }\end{array}$ & Company & $\begin{array}{l}\text { Outsourcing planned but } \\
\text { not executed }\end{array}$ & WUA & Company \\
\hline & Water metering & Company, opaque & $\begin{array}{l}\text { Outsourcing planned but } \\
\text { not executed }\end{array}$ & WUA & Company, transparent \\
\hline & Fertigation & Company & $\begin{array}{l}\text { Outsourcing planned but } \\
\text { not executed }\end{array}$ & $\begin{array}{l}\text { Partially, under WUA complete } \\
\text { control }\end{array}$ & Farmers individually \\
\hline & $\begin{array}{l}\text { Staff } \\
\text { management }\end{array}$ & Company & $\begin{array}{l}\text { WUA, except from } \\
\text { maintenance workers }\end{array}$ & $\begin{array}{l}\text { WUA, except from maintenance } \\
\text { workers }\end{array}$ & Company \\
\hline & $\begin{array}{l}\text { System } \\
\text { maintenance }\end{array}$ & Company & Company & $\begin{array}{l}\text { Company 2006-2018, exclusive } \\
\text { contract after } 2018\end{array}$ & Company \\
\hline \multirow[t]{4}{*}{$\begin{array}{l}\text { Economic } \\
\text { management }\end{array}$} & Billing & Company & $\begin{array}{l}\text { Outsourcing planned but } \\
\text { not executed }\end{array}$ & WUA & Company \\
\hline & Price setting & Company & $\begin{array}{l}\text { Outsourcing planned but } \\
\text { not executed }\end{array}$ & WUA & Company \\
\hline & Default rules & $\begin{array}{l}\text { Company, debt } \\
\text { transferred to WUA }\end{array}$ & WUA & WUA & $\begin{array}{l}\text { Company, negotiated with WUA in } \\
\text { case of long delay }\end{array}$ \\
\hline & $\begin{array}{l}\text { Abandonment } \\
\text { rules }\end{array}$ & Yes. Fines & WUA & WUA & Free abandonment \\
\hline
\end{tabular}

2017) and are essential to grasp the germ of collective-private hybridization in the recent coproduction processes of Valencian irrigation. Technology transfer was not accompanied by training and empowerment programs, or by considering users as the managers and governors of their own system, which has already been stressed by previous research (Vos \& Boelens, 2014; Romano, 2017; Dupuits, 2019). With the community as the collective governor, with some well-trained users, and with communities equipped with trained staff, it would not have been necessary to engage external services to resolve water management tasks that could have been resolved successfully by prevailing usercontrolled technologies.

Consequently, irrigator communities with weaker human capital, understood as the acquired knowledge and skills that an individual brings to an activity (Ostrom, 2000), have been the most prone to privatize their management. The small communities of Senyera or Pou de la Penya de l'Hedra had no expert personnel in drip irrigation, and therefore penetration by private companies affected a greater number of functions. By contrast, Acequia Real del Júcar, with more solid human capital, has been able to manage hybridization better, selecting those options that will prove more beneficial, or developing personnel training plans at the same time, to master the new infrastructure. They were even able to replace certain devices in this infrastructure to avoid being trapped by some building companies' strategies (using non-standardized devices) in order to make sure they are hired for maintenance services.

However, together with the existence of a trained group of technicians, the awareness of the value of collective water management is a critical factor that makes irrigation entities more resistant to external pressures for outsourcing. In Càrcer or Senyera, the community did not make the decision of outsourcing or privatizing unanimously. It was promoted by political agents linked directly or indirectly with the community of irrigators by ethically questionable practices. It is precisely in these cases in which collective-private collaboration was vehemently challenged by users aware of their historical and cultural tradition. In Acequia Real del Júcar, it was also the administration (Confederación Hidrográfica del Júcar) that urged irrigators to receive this external assistance. In this case the irrigator community, one of the most relevant representatives of historical collective management in the country, made sure to maintain close surveillance over the company's practices and to develop a training strategy to recover system management. In these three cases, farmers were proud of defending a cultural tradition, forms of collective action (knowledge, understandings, norms and rules) considered by numerous researchers as the social capital of irrigation (Ostrom, 2000; Uphoff \& Wijayaratna, 2000; Mustafa \& Qazi, 2007; Hoggesteger, 2013, 2015; Hunecke et al., 2017). On the contrary, the hybridization process followed a different path in the small community of Pou de la Penya de l'Hedra, without a significant culture and tradition of collective water management, and consequently a weak social capital. There, outsourcing did not lead to social conflicts and was welcomed by the farmers.

A comparison of Tecvasa's practices in Senyera with Operagua's in Pou de la Penya de l'Hedra show that the results of these hybridization processes does not depend only on the human capital, community rootedness, and the awareness of sharing collective irrigation management values, but also on the strategies followed by the private companies (see also Vos, Boelens, Venot, \& Kuper, 2020). In the former case we find a company that applied a short-term approach of trying to make the highest profit in a bounded, concrete time, and, in the latter case, a company that worked to consolidate a long-term relationship with the irrigation entity. Tecvasa minimized system maintenance actions, imposed severe non-abandonment clauses on irrigators, transferred any problems in fee-collecting from users to the entire irrigator community, and kept users from checking their water consumption. Operagua pursued none of such practices, satisfying users by doing proper maintenance, leaving them free to abandon the system, flexibly managing late payment under the water user entity's control, and facilitating system transparency by allowing users to read 
their flow meters. Transparency, considered a basic element for successfully governing the commons (Trawick, 2008; Hoogesteger, 2013), was a critical factor that allowed users to trust the private company, positioned as an intermediator between them and system's infrastructure and resources.

Definitely, Operagua understood that the community, at the end of the day, must decide about their own system's management, about fundamental decision-making regarding governance. This openness earned them users' trust (see also Baud (2018) on the notion of 'confianza'), the key to becoming part of community life, also a key factor in these processes of adoption of new technology (Hunecke et al., 2017; Nikkels, Kumar, \& Meinke, 2019). This strategy worked to strengthen, amidst complex relationships and adverse contexts, community spirit to achieve shared well-being in collective resource management (cf. Vos et al., 2020). These were determining factors to sustain company-community collaboration over time in Pou de la Penya de l'Hedra. Tecvasa never grasped this.

The comparison of the behavior of both companies helps understanding and eventually supporting hybridization strategies that may provide successful coproduction processes. Nevertheless, even when hybridization results in sustainable operation, incorporating private enterprise increases management costs. The company needs a profit margin, which raised costs in the cases analyzed. In a case such as Pou de la Penya de l'Hedra, it could be claimed that, for small entities (with relatively well-off smallholders who have multiple sources of income), it is more operational to have this private assistance, to achieve economies of scale. Even so, in such situations, it would be desirable for these small user-entities to reduce their costs by combining with other neighboring systems to share personnel and services. Upscaling by such nested institutions (Ostrom, 1990) or other forms of horizontal and vertical scalar reconfiguration (Duarte-Abadía, Boelens, \& Du Pré, 2019; Dupuits, Baud, Boelens, de Castro, \& Hogenboom, 2020; Hoogesteger, Boelens, \& Baud, 2016; Swyngedouw, 2009; Villamayor-Tomas \& García-López, 2018), would significantly enhance management and defense capacity (see also Hoogesteger, 2013; Vos et al., 2020). This option makes even more sense if we also consider that, in cases such as Pou de la Penya de l'Hedra, these entities do share the use of a single aquifer with other entities, and therefore can achieve other advantages as well by integrating into a higher-level common network.

\section{Conclusions}

Introducing drip irrigation definitely facilitates penetration of private enterprise into Spain's irrigation systems, altering relationships among their components and thus, altering water user collectives as sociotechnical and political subjects altogether. Users' capacity to guide this collective-private coproduction process and maintain local control over their irrigation systems is essential to ensure the stability and preserve the robustness of each irrigation system. This control of the irrigation system by users is probably the factor that ultimately draws the conceptual borderline between outsourcing of certain operating services and procedures and what we can consider irrigation systems' privatization. This consideration can help banish more ideological use of these terms.

Irrigation system users' capacity to keep local control while adopting new technologies depends on quite a diverse array of factors, but in regard to private enterprise insertion, the cases studied show the importance of human and social capital quality, their local rootedness, and recognition of how valuable collective water management is. These factors, which depend on the tradition, culture and size of the water user collectives, make irrigation entities more robust vis-à-vis external pressures and disturbances, which in some of the cases analyzed have generated major social conflicts.

Further, when the company incorporated into the irrigation system is able to understand and support the logic of collective action in irrigation, maintaining transparency, building trust and leaving control in users' hands, collective and private action can hybridize without producing existential conflict and without undermining the irrigation system's robustness - although it will nonetheless slightly increase operating costs.

\section{CRediT authorship contribution statement}

Marta García-Mollá: Conceptualization, Investigation, Writing original draft, Writing - review \& editing, Funding acquisition. Mar Ortega-Reig: Conceptualization, Investigation, Writing - original draft, Writing - review \& editing. Rutgerd Boelens: Conceptualization, Investigation, Writing - original draft, Writing - review \& editing. Carles Sanchis-Ibor: Conceptualization, Investigation, Writing - original draft, Writing - review \& editing, Funding acquisition.

\section{Acknowledgements}

This work has been done under the research project on Design and evaluation of strategies to adapt to global climate change in Mediterranean watersheds by using irrigation water intensively (ADAPTAMED) funded by the Ministry of Science, Innovation and Universities of Spain with FEDER funding.

\section{References}

Ahmadzadeh, H., Morid, S., Delavar, M., \& Srinivasan, R. (2015). Using the SWAT model to assess the impacts of changing irrigation from surface to pressurized systems on water productivity and water saving in the Zarrineh Rud catchment. Agricultural Water Management, 175, 15-28. https://doi.org/10.1016/j. agwat.2015.10.026.

Alcón, F., Arcas, N., De Miguel, M. D., \& Fernández-Zamundio, M. A. 2009. Adopción de tecnologías ahorradoras de agua en agricultura. In J. A. Gómez Limón et al. (Eds.), La economía de agua de riego en España. Una perspectiva regional. Almería: Fundación Cajamar.

Andersen, A. O. (2019). Assembling commons and commodities: The Peruvian water law between ideology and materialisation. Water Alternatives, 12(2), $470-487$.

Aubriot, O., Fernandez, S., Trottier, J., \& Fustec, K. (2018). Water technology, knowledge and power. Addressing them simultaneously. WIREs Water, 5. https://doi.org/10.1002/wat2.1261 e1261.

Bakker, K. (2005). Neoliberalizing Nature ? Market Environmentalism in Water Supply in England and Wales. Annals of the Association of American Geographers, 95(3), 542-565.

Bakker, K. (2013). Neoliberal versus Postneoliberal Water: Geographies of Privatization and Resistance. Annals of the Association of American Geographers, 103(2), 253-260.

Baud, M. (2018). Confianza: Governance and Trust in Latin America and the Netherlands. Valedictory lecture. CEDLA, University of Amsterdam.

Berbel, J., Gutiérrez-Martín, C., Rodríguez-Díaz, J. A., Camacho, E., \& Montesinos, P. (2015). Literature review on rebound effect of water saving measures and analysis of a Spanish case study. Water Resources Management, 29(3), 663-678.

Boelens, R. (2015). Water, Power and Identity. The Cultural Politics of Water in the Andes. London and Washington, D.C: Routledge/Earthscan.

Boelens, R., Hoogesteger, J., \& Baud, M. (2015). Water reform governmentality in Ecuador: Neoliberalism, centralization, and the restraining of polycentric authority and community rule-making. Geoforum, 64, 281-291.

Boelens, R., Shah, E., \& Bruins, B. (2019). Contested Knowledges: Large Dams and Mega-Hydraulic Development. Water, 11(3), 416. https://doi.org/10.3390/ w11030417.

Bond, P. (2004). Water Commodification and Decommodification Narratives: Pricing and Policy Debates from Johannesburg to Kyoto to Cancun and Back. Capitalism, Nature, Socialism, 15, 7-24.

Brandshaug, M. K. (2019). Water as more than commons or commodity: Understanding water management practices in Yanque, Peru. Water Alternatives, 12(2), 538-553.

Bridge, G. \& Perreault, T. (2009). Environmental governance. In N. Castree, D. Demeritt, D. Liverman, \& B. Rhoads (Eds.), Companion to Environmental Geography (pp. 475-497). Oxford: Blackwell.

Calatayud, S. (2008). Cambios institucionales en el regadío valenciano, 1830-1866. Ayer, 69, 221-252.

Caamaño, F., Gimeno, J. M., Quintero, G., \& Sala, P. (2017). Servicios públicos e ideología. El interés general en juego. Barcelona: Ed. Profil. 
Cai, X., Rosegrant, M. W., \& Ringler, C. (2003). Physical and economic efficiency of water use in the river basin: Implications for efficient water management Water Resources Research, 39(1). https://doi.org/10.1029/2001WR000748.

Cifdaloz, O., Regmi, A., Anderies, J. M., \& Rodríguez, A. A. (2010). Robustness, vulnerability, and adaptive capacity in small-scale social-ecological systems: the Pumpa Irrigation system in Nepal. Ecology and Society, 15(3), 39 http:// www.ecologyandsociety.org/vol15/iss3/art39/.

Contor, B. A., \& Taylor, R. G. (2013). Why improving irrigation efficiency increases total volume of consumptive use. Irrigation and Drainage, 62(3), 273-280. https://doi.org/10.1002/ird.1717.

D’Amaro, F. (2018). Pozos y mafiosos. La inacabada transicióndel mercado del agua a la gestión colectiva en el Palermo del siglo XX. Cuadernos de Geografía, 101, 71-90.

Del Campo, A. (2018). The irrigators communities of Spain and their national federation, FENACORE.

Dupuits, E. (2019). Water community networks and the appropriation of neoliberal practices: Social technology, depoliticization, and resistance. Ecology and Society, 24(2), 20. https://doi.org/10.5751/ES-10857-240220.

Dupuits, E., Baud, M., Boelens, R., de Castro, F., \& Hogenboom, B. (2020). Scaling up but losing out? Water commons' dilemmas between transnational movements and grassroots struggles in Latin America. Ecological Economics, 172. https://doi. org/10.1016/j.ecolecon.2020.106625 106625.

Fernández-García, I., Rodríguez-Díaz, J. A., Camacho-Poyato, E., Montesinos, P., \& Berbel, J. (2014). Effects of modernization and medium term perspectives on water and energy use in irrigation districts. Agricultural Systems, 131, 56-63.

Garb, Y., \& Friedlander, L. (2014). From transfer to translation: Using systemic understandings of technology to understand drip irrigation uptake. Agricultural Systems, 128, 13-24. https://doi.org/10.1016/j.agsy.2014.04.003.

Garcés-Restrepo, C., Vermillion, D. L., \& Muñoz, G. (2007). Irrigation management transfer. FAO, Rome: Worldwide efforts and results.

ESYRCE (2019). Encuesta de superficies y rendimientos de Cultivos de España, Ministerio de Agricultura, Pesca y Alimentación, https://www.mapa.gob.es/es/ estadistica/temas/ estadisticas-agrarias/agricultura/esyrce/.

García-Mollá, M., Sanchis-Ibor, C., Avellá-Reus, L., Albiac, J., Isidoro, D., \& Lecina, S. (2019). Spain. In F. MolleSanchis-Ibor \& L. Avellà (Eds.), Irrigation in the Mediterranean. Technologies, Intitutions and Policies (pp. 89-122). Cham, Switzerland: Springer.

García-Mollá, M., Sanchis-Ibor, C., Ortega, M. V., \& Avellà, L. (2013). Irrigation associations coping with drought: the case of four irrigation districts in Eastern Spain. In K. Schwabe, J. Albiac, J. D. Connor, R. M. Hassan, \& L. Meza (Eds.), Drought in Arid and Semi-Arid Regions. A multi-disciplinary and Cross-Country Perspective (pp. 101-121). New York: Springer.

Glick, T. F. (1970). Irrigation and society in medieval Valencia. Cambridge: Harvard University Press.

Goodwin, G. (2019). The problem and promise of coproduction: Politics, history, and autonomy. World Development, 122, 501-513.

Grafton, R.Q., Williams, J., Perry, C.J., Molle, F., Ringler, C., Steduto, P., Udall, B., Wheeler, S.A., Wang, Y., Garrick, D. \& Allen, R.G. (2018). The paradox of irrigation efficiency. Science, 361(6404): 748-750.

Groenfeldt, D., \& Svendsen, M. (2000). Case studies in participatory irrigation management. Washington, D.C: World Bank Institute.

Harvey, D. (2003). The New Imperialism. New York: Oxford University Press.

Hoogesteger, J. (2013). Trans-Forming social capital around water: Water user organizations, water rights, and Nongovernmental Organizations in Cangahua, the Ecuadorian Andes. Society \& Natural Resources, 26(1), 60-74.

Hoogesteger van Dijk, J. 2017. An elite technology? Drip irrigation, agro-export and agricultural policies in Guanajuato, Mexico. In: Venot, J-P., Marcel, K. \& Margreet, Z. (eds.). Drip Irrigation for Agriculture: Untold Stories of Efficiency, innovation and Development. Oxon: Earthscan/Routledge, pp. 151-166.

Hoogesteger, J. (2015). Normative structures, collaboration and conflict in irrigation; a case study of the Píllaro North Canal Irrigation System, Ecuadorian Highlands. International Journal of the Commons., 9(1), 398-415.

Hoogesteger, J., Boelens, R., \& Baud, M. (2016). Territorial pluralism: Water users' multi-scalar struggles against state ordering in Ecuador's highlands. Water International, 41(1), 91-106.

Houdret, A. (2012). The water connection: Irrigation, water grabbing and politics in southern Morocco. Water Alternatives, 5(2), 284-303.

Houdret, A., \& Bonnet, S. (2013). Public-private partnerships in irrigation management: socioeconomic, political and environmental concerns. European Consortium for Political Research General Conference, Bordeaux.

Hunecke, C., Engler, A., Jara-Rojas, R., \& Marijn Poortvliet, J. (2017). Understanding the role of social capital in adoption decisions: An application to irrigation technology. Agricultural Systems, 153, 221-231. https://doi.org/10.1016/j. agsy.2017.02.002.

Jackson, S. (2018). Water and Indigenous rights: Mechanisms and pathways of recognition, representation, and redistribution. WIREs Water, 5, online. https:// doi.org/10.1002/wat2.1314.

Jansen, K., \& Vellema, S. (2011). What is technography? NJAS-Wageningen Journal of Life Sciences, 57(3), 169-177.

Kibaroglu, A. (2020). The role of irrigation associations and privatization policies in irrigation management in Turkey. Water International, 45(2), 83-90. https://doi. org/10.1080/02508060.2020.1719382.

Jasanoff, S. (2004). States of knowledge: The co-production of science and social order. Abingdon: Routledge.
Joshi, A., \& Moore, M. (2004). Institutionalised co-production: Unorthodox public service delivery in challenging environments. Journal of Development Studies, 40 (4), 31-49.

Lobina, E., Kishimoto, S., \& Petitjean, O. (2015). Here to stay: Water remunicipalisation as a global trend. London: Transnational Institute.

Lobina, E., Weghmann, V., \& Marwa, M. (2019). Water justice will not be televised: Moral advocacy and the struggle for transformative remunicipalisation in Jakarta. Water Alternatives, 12(2), 725-748.

López-Gunn, E., Zorrilla, P., Prieto, F., \& Llamas, R. (2012). Lost in translation? Water efficiency in Spanish agriculture. Agricultural Water Management, 108, 83-95.

Maass, A., \& Anderson, R. L. (1978)....And the desert shall rejoice: Conflict, growth and justice in arid environments. Cambridge: MIT Press.

Mabry, J. B. (1996). Canals and Communities: Small-Scale Irrigation Systems. University of Arizona Press.

Mandri-Perrott, C., \& Bisbey, J. (2016). How To Develop Sustainable Irrigation Projects with Private Sector Participation. World Bank, Cambridge Economic Policy Associates and PPIAF.

Mayer, E. (2002). The Articulated Peasant: Household Economies in the Andes. Boulder US: Westview press.

Mitlin, D. (2008). With and beyond the state: Co-production as a route to political influence, power and transformation for grassroots organizations. Environment and Urbanization, 20(2), 339-360.

Mustafa, D., \& Qazi, M. U. (2007). Transition from Karez to Tubewell Irrigation: Development, Modernization, and Social Capital in Balochistan, Pakistan. World Development, 35(10), 1796-1813.

Nikkels, M. J., Kumar, S., \& Meinke, H. (2019). Adaptive irrigation infrastructure linking insights from human-water interactions and adaptive pathways. COSUST, 40, 37-42. https://doi.org/10.1016/j.cosust.2019.09.001.

Ortega-Reig, M., Sanchis-Ibor, C., García-Mollá, M., \& Palau-Salvador, G. (2017) Institutional and management implications of drip irrigation introduction in collective irrigation systems in Spain. Agricultural Water Management, 187, 164-172. https://doi.org/10.1016/j.agwat.2017.03.009.

Ostrom, E. (1990). Governing the commons: The evolution of institutions for collective action. Cambridge, UK: Cambridge University Press.

Ostrom, E. (1992). Crafting institutions for self-governing irrigation systems. San Francisco, United States: ICS Press.

Ostrom, E. (2000). Social capital: A fad or a fundamental concept. Social capital: A multifaceted perspective, 172(173), 19-98.

Ostrom, E. (1996). Crossing the great divide: Coproduction, synergy and development. World Development, 24(6), 1073-1087.

Paerregaard, K. (2019). Liquid accountability: Water as a common, public and private good in the Peruvian Andes. Water Alternatives, 12(2), 488-502.

Perreault, T. (2008). Custom and Contradiction: Rural Water Governance and the Politics of Usos y Costumbres in Bolivia's Irrigator Movement. Annals of the Association of American Geographers, 98(4), 834-854.

Pigeon, M., McDonald, D. A., Hoedeman, O., \& Kishimoto, S. (Eds.). (2012). Remunicipalisation: Putting water back into public hands. Amsterdam: Transnational Institute.

Préfol, B., Tardieu, H., Vidal, A., Fernandez, S., Plantey, J., \& Darghout, S. (2006) Public-private partnership in irrigation and drainage: Need for a professional third-party between farmers and government. Irrigation and Drainage, 55, $253-263$.

Rap, E. (2006). The success of a policy model: Irrigation management transfer in Mexico. The Journal of Development Studies, 42(8), 1301-1324. https://doi.org/ $10.1080 / 00220380600930606$.

Reimer, B., Lyons, T., Ferguson, N., \& Polanco, G. (2008). Social Capital as Social Relations: The Contribution of Normative Structures. Sociological Review, 56(2), 256-274.

Rodríguez-Díaz, J. A., Pérez-Urrestarazu, L., Camacho-Poyato, E., \& Montesinos, P. (2011). The paradox of irrigation scheme modernization: More efficient water use linked to higher energy demand. Spanish Journal of Agricultural Research, 9 (4), 1000-1008

Roth, D. (2014). Environmental sustainability and legal plurality in irrigation: The Balinese subak. COSUST, 11, 1-9.

Roth, D., Boelens, R., \& Zwarteveen, M. (2015). Property, legal pluralism, and water rights: The critical analysis of water governance and the politics of recognizing "local" rights. Journal of Legal Pluralism and Unofficial Law, 47(3) 456-475.

Romano, S. (2017). Building Capacities for Sustainable Water Governance at the Grassroots: "Organic Empowerment" and Its Policy Implications in Nicaragua. Society \& Natural Resources, 30(4), 471-487.

Sanchis-Ibor, C., García-Mollá, M., Calafat, C., \& Vega, V. (2009). Las entidades de riego en común. Aspectos institucionales. In J. A. Gómez-Limón, A. Garrido, J. Calatrava-Leyva, F. J. Sáez-Fernández, \& A. Xabadía (Eds.), La Economía del Agua de Riego en España Almería (pp. 75-92). España: Fundación Cajamar.

Sanchis-Ibor, C., García-Mollá, M., \& Avellà, L. (2016). Las políticas de implantación del riego localizado. Efectos en las entidades de riego de la Comunidad Valenciana Boletín de la Asociación de Geógrafos Españoles, 72, 9-35. https://doi.org/ 10.21138/bage.2330.

Sanchis-Ibor, C., Boelens, R., \& García-Mollá, M. (2017). Collective irrigation reloaded. Re-collection and re-moralization of water management after privatization in Spain. Geoforum, 87, 38-47. https://doi.org/10.1016/ j.geoforum.2017.10.002.

Sanchis-Ibor, C., García-Mollá, M., \& Avellà, L. (2017). Effects of drip irrigation promotion policies on water use and irrigation costs in Valencia, Spain. Water Policy, 19(1), 165-180. https://doi.org/10.2166/wp.2016.025. 
Savas, E. S. (1987). Privatising: The Key to Better Government Chathas. New Jersey: Chathas House Publishers.

Savas, E. S. (1999). Privatization and Public-Private Partnerships. New York: CQ Press.

Soto-García, M., Martínez-Alvarez, V., García-Bastida, P. A., Alcon, F., \& MartinGorriz, B. (2013). Effect of water scarcity and modernisation on the performance of irrigation districts in south-eastern Spain. Agricultural Water Management, 124, 11-19. https://doi.org/10.1016/j.agwat.2013.03.019.

Stensrud, A. B. (2019). The Social Embeddedness of Hydraulic Engineers in the Regulation of Water and Infrastructure in Peru. Environment and Planning C: Politics and Space, 37(7), 1235-1251.

Suhardiman, D., Nicol, A., \& Mapedza, E. (Eds.). (2017). Water Governance and Collective Action. Multi-scale Challenges. London and New York: Routledge.

Swyngedouw, E. (2005). Dispossessing $\mathrm{H}_{2} \mathrm{O}$ : The Contested Terrain of Water Privatization. Capitalism Nature Socialism, 16(1), 81-98.

Swyngedouw, E. (2009). The political economy and political ecology of the hydrosocial cycle. Journal of Contemporary Water Research \&' Education, 142 56-60.

Trawick, P. (2008). Scarcity, Equity, and Transparency: General Principles for Success in Local Water Management. In E. Wietgand (Ed.), Mountains: Sources of Water, Sources of Knowledge (pp. 43-61). Dodrecht and Netherlands: Springer.

Trier, R. (2014). Review of international experience with public-private partnership in the Irrigation subsector. Irrigation and drainage, 63, 212-220.

Ullberg, S. B. (2019). Making the megaproject: Water infrastructure and hydrocracy at the public-private interface in Peru. Water Alternatives, 12(2) 503-520.
Uphoff, N., \& Wijayaratna, C. M. (2000). Demonstrated Benefits from Social Capital: The Productivity of Farmer Organizations in Gal Oya, Sri Lanka. World Development, 28(11), 1875-1890.

Van der Kooij, S., Zwarteveen, M., Boesveld, H., \& Kuper, M. (2013). The efficiency of drip irrigation unpacked. Agricultural Water Management, 123(3), 103-110.

Venot, J. P., Kuper, M., \& Zwarteveen, M. (Eds.). (2017). Drip Irrigation: Untold Stories of Efficiency, Innovation \& Development. London: Earthscan/Routledge.

Vermillion, D. L. (1997). Impacts of irrigation management transfer: A review of evidence, Research Report 11. Colombo, Sri Lanka: International Irrigation Management Institute.

Villamayor-Tomas, S., \& García-López, G. (2018). Social movements as key actors in governing the commons: Evidence from community-based resource management cases across the world. Global Environmental Change, 53, 114-126.

Vos, J., \& Boelens, R. (2014). Sustainability Standards and the Water Question. Development and Change, 45(2), 205-230.

Vos, J., Boelens, R., Venot, J. P., \& Kuper, M. (2020). Rooted water collectives: Towards an analytical framework. Ecological Economics, 173. https://doi.org/ 10.1016/j.ecolecon.2020.106651 106651.

Wilson, N. J. (2019). Seeing Water Like a State?": Indigenous water governance through Yukon First Nation Self-Government Agreements. Geoforum, 104 101-113. https://doi.org/10.1016/j.geoforum.2019.05.003.

World Bank. 2007. Emerging Public-Private Partnerships in Irrigation Development and Management, The World Bank, Washington D.C.

World Bank. 2005. Shaping the Future of Water for Agriculture. A Sourcebook for Investment in Agricultural Water Management, The World Bank, Washington D.C. 